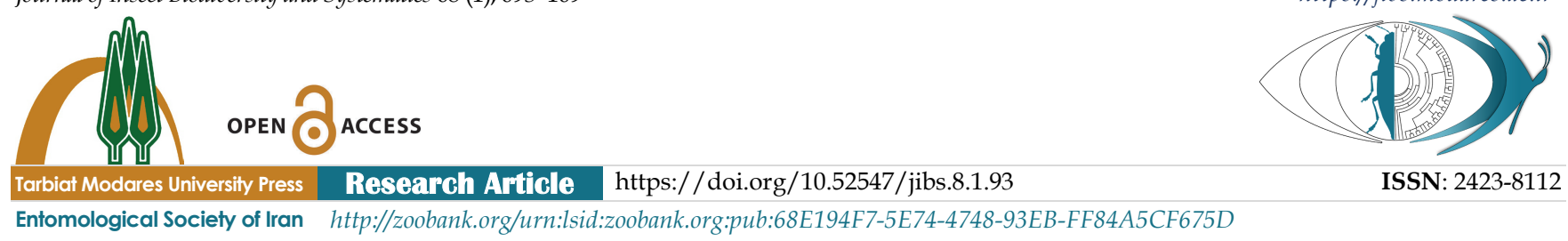

\title{
On the Ophioniformes group (Hymenoptera: Ichneumonidae) from Kerman province with six new records to Iran
}

\author{
Negar Bahremand \\ Department of Plant Protection, College of Agriculture, Shahid Bahonar University of Kerman, Kerman, Iran. \\ $\triangle$ negar_bahremand12@yahoo.com; (iD https://orcid.org/0000-0002-2302-4764 \\ Mohammad Khayrandish \\ Department of Plant Protection, College of Agriculture, Shahid Bahonar University of Kerman, Kerman, Iran. \\ $\triangle$ m.khayrandish@uk.ac.ir; (iD http://orcid.org/0000-0002-2568-2306 \\ Abbas Mohammadi-Khoramabadi \\ Department of Plant Production, College of Agriculture and Natural Resources of Darab, Shiraz University, Fars, Iran. \\ هmohamadk@Shirazu.ac.ir; (iD http://orcid.org/0000-0001-6711-9952 \\ Matthias Riedel \\ Klinik Fallingbostel, Kolkweg 1, D-29683 Bad Fallingbostel, Germany. \\ هmamaflo.riedel@t-online.de; (iD http://orcid.org/0000-0001-5747-1223 \\ Received: \\ 29 October, 2021 \\ Accepted: \\ 10 December, 2021 \\ Published: \\ 05 January, 2022 \\ ABSTRACT. The fauna of the Ophioniformes group (Hym.: Ichneumonidae) was \\ studied in the southern part of Kerman province, Iran during 2014-2015. Four localities \\ (Faryab, Jiroft, Maskoon and Sarbijan) have been surveyed using eight Malaise traps. Two \\ traps were operated in each location. A total of 135 specimens of the Ophioniformes group \\ have been collected and identified representing 27 species into seven subfamilies and 17 \\ genera. One genus (i.e. Meloboris Holmgren, 1859) and six species are reported from Iran \\ for the first time: Diadegma kyffhusanae Horstmann, 1973, Hyposoter barretti (Bridgman, \\ 1881), Hyposoter caudator Horstmann, 2008, Meloboris collector (Thunberg, 1822), Sinophorus \\ pleuralis (Thomson, 1887) and Mesochorus arenarius (Haliday, 1838). Fifteen species are \\ newly recorded from Kerman province. The biographical and altitudinal range \\ distribution, as well as adult flight period of the identified species, are also discussed. \\ Subject Editor: \\ Maryam Zardouei-Heydari Key words: parasitoid, taxonomy, distribution, new records, highlands
}

Citation: Bahremand, N., Khayrandish, M., Mohammadi-Khoramabadi, A. \& Riedel, M. (2022) On the Ophioniformes group (Hymenoptera: Ichneumonidae) from Kerman province with six new records to Iran. Journal of Insect Biodiversity and Systematics, 8 (1), 093-109.

\section{INTRODUCTION}

The Ophioniformes is a major monophyletic group of the family Ichneumonidae (Insecta: Hymenoptera) based on $28 \mathrm{~S}$ rDNA sequences and morphological data and currently comprises 16 subfamilies (Quicke et al., 2009). Members of this group are biologically mainly koinobiont parasitoids of Lepidoptera and Hymenoptera and less commonly of Coleoptera and Symphyta (members of the subfamily Tersilochinae) (Quicke, 2015). Study on the Iranian fauna of the Ophioniformes have received more attention recently. Barahoei et al. (2012b) listed 163 species of the Ophioniformes group; Anomaloninae (11), Banchinae (10), Campopleginae (36), Cremastinae (22), Ctenopelmatinae (9), 
Hybrizontinae (1), Mesochorinae (1), Metopiinae (7), Ophioninae (19), Tersilochinae (4) and Tryphoninae (43), respectively from Iran. Later, more species of this group were discovered through ecological or faunistic studies (Kishani-Farahani et al., 2012; Barahoei et al., 2012a, 2013, 2014, 2015; AkbarzadehShoukat, 2012; Abbasipour et al., 2013; Hooshyar \& Vafaei-Shoushtari, 2013, 2014; Nikdel \& Diller, 2014; Hasanshahi et al., 2015a, 2015b, 2015c; Shamszadeh et al., 2015; Sarafi et al., 2015; Amiri et al., 2015a, 2015b, 2016a, 2016b, 2017 ; Mohebban et al., 2016; Shaw et al., 2016; Mohammadi-Khoramabadi et al., 2016a, 2016b, 2017, 2018, 2020a, 2020b; Kolarov, 2016; Pourhaji et al., 2016; MohammadiKhoramabadi \& Ziaaddini, 2017; Hooshyar et al., 2017; Bahremand et al., 2017; Schnee, 2018; Riedel, 2018, 2021; Riedel et al., 2019a, 2019b; Zardouei-Heydari et al., 2019, 2020a, 2020b, 2020c; Falahatpisheh et al., 2021; Johansson, 2021; Johansson et al., 2021).

Jiroft and Faryab counties, locating at the south of Kerman province, are known as two major agricultural producing regions of Iran (Ebadzadeh et al., 2018). The mountain ranges of Jebal Barez with wide gradients of elevation from about 600 (in Jiroft and Faryab) to more than $3000 \mathrm{~m}$ a.s.l. (in Sarbijan), fertile plains and topographic heterogeneity provide suitable habitats for a diverse and endemic taxa (Noroozi, 2020). In order to improve the knowledge on the fauna of Ichneumonidae in Iran, this study was conducted to survey the fauna of the Ophioniformes group in various agricultural ecosystems of Jiroft and Faryab counties of Kerman province, Iran.

\section{MATERIAL AND METHODS}

Four regions of southern part of Kerman province belonging to Jiroft (Jiroft, Maskoon and Sarbijan) and Faryab counties (Table 1) were selected. Different climatological conditions i.e., cold and moderate mountainous, warm-dry and warm-humid in this area favored a highly prosperous situation for inhabiting a very diverse vegetation as well as developing agricultural activities. The ichneumonid specimens were collected using eight Malaise traps (MT1-MT8) which were installed in different agricultural ecosystems from March 2014 to August 2015 by N. Bahremand (N.B.) and A. MohammadiKhoramabadi (A.M.K.).

Table 1. Geographical coordinates of Malaise traps in the studied areas of Kerman province, Iran during 2014-2015.

\begin{tabular}{|c|c|c|c|c|}
\hline Trap \# & Location & Position & Elevation (m) & Vegetation \\
\hline MT1 & Faryab & $\begin{array}{l}28^{\circ} 05^{\prime} 26^{\prime \prime} \mathrm{N} \\
57^{\circ} 13^{\prime} 50^{\prime \prime} \mathrm{E}\end{array}$ & 640 & alfalfa, palm \\
\hline MT2 & Faryab & $\begin{array}{l}28^{\circ} 04^{\prime} 58^{\prime \prime} \mathrm{N} \\
57^{\circ} 13^{\prime} 41^{\prime \prime} \mathrm{E}\end{array}$ & 640 & alfalfa, palm, wheat \\
\hline MT3 & Jiroft & $\begin{array}{l}28^{\circ} 34^{\prime} 38^{\prime \prime} \mathrm{N} \\
57^{\circ} 51^{\prime} 41^{\prime \prime} \mathrm{E}\end{array}$ & 855 & Orchard (citrus, olive) \\
\hline MT4 & Jiroft & $\begin{array}{l}28^{\circ} 33^{\prime} 14^{\prime \prime} \mathrm{N} \\
57^{\circ} 51^{\prime} 48^{\prime \prime} \mathrm{E}\end{array}$ & 855 & alfalfa, citrus, palm \\
\hline MT5 & Maskoon & $\begin{array}{l}28^{\circ} 51^{\prime} 41^{\prime \prime} \mathrm{N} \\
57^{\circ} 52^{\prime} 10^{\prime \prime} \mathrm{E}\end{array}$ & 1665 & pomegranate, walnut, fig \\
\hline MT6 & Maskoon & $\begin{array}{l}28^{\circ} 51^{\prime} 44^{\prime \prime} \mathrm{N} \\
57^{\circ} 51^{\prime} 58^{\prime \prime} \mathrm{E}\end{array}$ & 1665 & alfalfa, bean \\
\hline MT7 & Sarbijan & $\begin{array}{l}29^{\circ} 06^{\prime} 57^{\prime \prime} \mathrm{N} \\
57^{\circ} 32^{\prime} 29^{\prime \prime} \mathrm{E}\end{array}$ & 3043 & peach, apple \\
\hline MT8 & Sarbijan & $\begin{array}{l}29^{\circ} 06^{\prime} 10^{\prime \prime} \mathrm{N} \\
57^{\circ} 32^{\prime} 46^{\prime \prime} \mathrm{E}\end{array}$ & 3043 & cherry, apricot \\
\hline
\end{tabular}


Geographical coordinates and the vegetation around each Malaise trap were presented in Table 1. Collecting bottles were filled by $75 \%$ ethanol, and the captured specimens were collected by two weeks intervals. The collected specimens were prepared according to AXA method (van Achterberg, 2009), then pinned or card mouned. Species of Campopleginae (the genera Campoletis, Hyposoter, Meloboris and Sinophorus) and Mesochorinae were determined by comparing with the type specimens of this group in Zoologische Staatssammlung Munich, Germany (ZSM) by the fourth author (Dr. M. Riedel) and the others by keys and description provided by Broad \& Shaw (2016), Horstmann (2013), Johansson \& Cederberg (2019), Schnee (2014), Kasparyan (1981b), Kasparyan \& Tolkanitz (1999), Johansson (2018), Tolkanitz (2007), Tolkanitz (2015). The identified specimens were deposited in the Insect Collection of Department of Plant Protection, Shahid Bahonar University of Kerman, Iran, Department of Plant Production, College of Agriculture and Natural Resources of Darab, Shiraz University (DCS), Iran and in Zoologische Staatssammlung, Munich, Germany (ZSM). General distribution map of the newly reported species was generated using ArcGIS 3.1 and Adobe Photoshope CS5 softwares based on the distribution data available on Yu et al. (2016); Belokobylskij et al. (2019); Klopfstein et al. (2019); Pénigot (2021).

\section{RESULTS}

In a total, 135 specimens of the Ophioniformes group were collected during 2014-2015 representing 27 species into seven subfamilies. Of which one genus (i. e. Meloboris Holmgren, 1859) and six species are stated to be recorded from Iran for the first time, indicated by double asterisks $\left(^{* *}\right)$. Fifteen species are also newly reported from Kerman province, indicated by single $\left(^{*}\right)$ asterisk.

\section{Taxonomic Hierarchy}

Family Ichneumonidae Latreille, 1802

Subfamily Anomaloninae Viereck, 1918

Tribe Anomalonini Viereck, 1918

\section{Genus Anomalon Panzer, 1854}

\section{Anomalon cruentatum (Geoffroy, 1785)}

Material Examined: 1 (DCS), Iran, Jiroft, MT3, 29.V.2015, Leg.: N.B..

Distribution within Iran: Ardabil (Masnadi-Yazdinejad \& Jussila, 2009), Isfahan (Barahoei et al., 2015; Zardouei-Heydari et al., 2020a), Fars and Kerman (Ghahari \& Jussila, 2016), Current study, Qazvin (Ghahari \& Schwarz, 2012), Khorasan-e-Razavi (Barahoei et al., 2014; Zardouei-Heydari et al., 2020a), Kermanshah (Zardouei-Heydari et al., 2020a), Mazandaran (Hooshyar \& Vafaei-Shoushtari, 2014), North Khorasan (Zardouei-Heydari et al., 2020a), Sistan and Baluchistan (Barahoei et al., 2012a), South Khorasan (Zardouei-Heydari et al., 2020a),Yazd (Zarepour-Ashkezari et al., 2009), West Azerbaijan (Mohammadi-Khoramabadi et al., 2020a) provinces.

General distribution: Oriental and Palaearctic (Yu et al., 2016; Klopfstein et al., 2019; Belokobylskij et al., 2019; Pénigot, 2021).

Family Ichneumonidae Latreille, 1802

Subfamily Campopleginae Förster, 1869

Genus Campoletis Förster, 1869

Campoletis scyticus Riedel, 2017

Material examined: 3우, Iran, Faryab, MT1 and MT2, 14.V.2014; 1어, Jiroft, MT3, 30.III.2014; 1ㅇ, Sarbijan, MT8, 30. III.2014, leg.: N.B. (DCS).

Distribution within Iran: Kerman province (Mohammadi-Khoramabadi et al., 2018); Current study. 
General distribution: Bulgaria, Kazakhstan, Kyrgyzstan, Morocco, Turkey, Turkmenistan (Riedel, 2017), Iran (Mohammadi-Khoramabadi et al., 2018), and Afghanistan (Vas, 2019).

Genus Casinaria Holmgren, 1859

Casinaria tenuiventris (Gravenhorst, 1829)*

Material examined: 1ㅇ, Iran, Jiroft, MT4, 30.III.2014; 10ิ, Maskoon, MT5, 23.VI.2015, leg.: N.B. (ZSM).

Distribution within Iran: Tehran (Masnadi-Yazdinejad et al., 2010) and Kerman provinces (Current study).

General distribution: Austria, Bulgaria, Czechia (Bohemia, Moravia), France, Italy, Norway, Russia (Caucasus), United Kingdom (Riedel, 2018).

Genus Cymodusopsis Viereck, 1912

Cymodusopsis persicus Riedel, 2019

Material examined: 1 ( (ZSM), Iran, Sarbijan, MT7, 20. IV. 2014, leg.: A.M.K..

Distribution within Iran: Kerman province (Riedel et al., 2019b); Current study.

General distribution: Iran (Riedel et al., 2019b).

Genus Diadegma Förster, 1869

Diadegma anurum (Thomson, 1887)*

Material examined: 1요, Iran, Jiroft, MT3, 30.III.2014, 1ㅇ 10, 21. IV.2014, leg.: N.B. (DCS).

Distribution within Iran: Fars (Falahatpisheh et al., 2021), Golestan (Masnadi-Yazdinejad et al., 2010), Tehran (Hasanshahi et al., 2014), and Kerman provinces (Current study).

Remarks: Reporting of this species from Alborz province (Golizadeh et al., 2008) was based on a misidentification (Karimzadeh \& Broad, 2013).

General distribution: Western Palaearctic (Europe) (Yu et al., 2016).

Diadegma armillatum (Gravenhorst, 1829)

Material examined: 2우, Iran, Faryab, MT1, 21.IV.2014; 4우의 same locality, MT2, 14.V.2014; 1우, Jiroft, MT4, 30.III.2014; 2우, same locality, 14.V.2014, leg.: N.B. (DCS).

Distribution within Iran: East Azerbaijan (Masnadi-Yazdinejad et al., 2010) and Kerman provinces (Mohammadi-Khoramabadi et al., 2016a); Current study.

General distribution: Australasian and Palaearctic (Yu et al., 2016).

Diadegma fenestrale (Holmgren, 1860)*

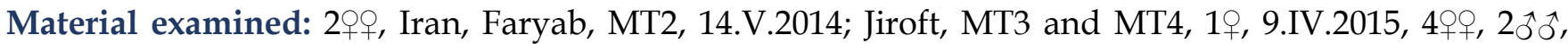
13.III.2015, 1ㅇ, 30.III.2014; Maskoon, MT5 and MT6, 11수, 24.V.2015, 1우, 23.VI.2015; Sarbijan, MT7, 1우, 30.III.2014, 1ㅇ, 21.IV.2014, leg.: N.B. (DCS).

Distribution within Iran: Fars (Falahatpisheh et al., 2021), Isfahan (Ghahari et al., 2012) and Kerman provinces (Current study).

General distribution: Oriental, Oceanic and Palaearctic (Yu et al., 2016).

Diadegma kyffhusanae Horstmann, 1973**

Material examined: 1요 Iran, Faryab, MT1, 14.V.2014, leg.: N.B. (DCS).

Distribution within Iran: Kerman province (Current study).

General distribution: Western Palaearctic (Yu et al., 2016), new record from Iran. 


\section{Diadegma maculatum (Gravenhorst, 1829)*}

Material examined: 1의, Iran, Maskoon, MT5, 1.V.2015; Sarbijan, MT8, 1ㅇ, 30.III.2014, leg.: N.B. (DCS).

Distribution within Iran: East Azerbaijan (Mohammadi-Khoramabadi et al., 2020a), West Azerbaijan (Pourhaji et al., 2016) and Kerman provinces (Current study).

General distribution: Western Palaearctic (Yu et al., 2016).

Diadegma majale (Gravenhorst, 1829)

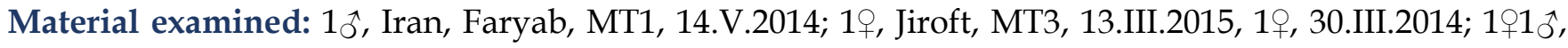
Maskoon, MT6, 1.V.2015, leg.: N.B. (DCS)

Distribution within Iran: Fars (Masnadi-Yazdinejad et al., 2010), Ardabil (Fathi et al., 2012); Kerman (Mohammadi-Khoramabadi et al., 2016a; current study); Markazi and Khuzestan provinces (Riedel et al., 2019a).

General distribution: Western Palaearctic (Yu et al., 2016).

Diadegma semiclausum (Hellén, 1949)

Material examined: 1엉 Iran, Sarbijan, MT7, 21.IV.2014, leg.: N.B. (DCS).

Distribution within Iran: Isfahan (Ghahari et al., 2012), Qazvin (Ghahari \& Schwarz, 2012), Kerman (Mohammadi-Khoramabadi et al., 2016a), Khorasan-e Razavi (Barahoei et al., 2014); Sistan and Baluchestan (Barahoei et al., 2013) and Fars provinces (Sarafi et al., 2015).

General distribution: Afrotropical, Australasian, Oceanic, Oriental, Palaearctic (Yu et al., 2016).

Genus Enytus Cameron, 1905

Enytus apostatus (Gravenhorst, 1829)*

Material examined: 1ㅇ, Iran, Faryab, MT1, 21.IV.2014; 2우, Jiroft, MT3 and MT4, 2.V.2015, 4우1 $\hat{\jmath}$, 9.IV.2015, 19, 21.IV.2014, leg.: N.B. (DCS).

Distribution within Iran: West Azerbaijan (Masnadi-Yazdinejad et al., 2010; Akbarzadeh-Shoukat, 2012), East Azerbaijan (Lotfalizadeh et al., 2012), Tehran, Qazvin (Sooudi et al., 2007) and Kerman provinces (Current study).

General distribution: Afrotropical, Nearctic, Oriental, Western Palearctic (Yu et al., 2016).

Genus Hyposoter Förster, 1869

Hyposoter barretti (Bridgman, 1881)** (Fig. 1A)

Material examined: 3ㅇ (DCS), Iran, Faryab, MT1 and MT2, 14.V.2014; 2 ㅇ (ZSM), Jiroft, MT3 and MT4, 21.IV.2014, 1 ㅇ (DCS), 30.III.2014, 1 ㅇ (DSC), 2.V.2015; 1수 (DCS), Maskoon, MT5 and MT6, 1.V.2015, 2 우 (DCS), 18.VI.2015; 1우 (DCS), Sarbijan, MT7 and MT8, 30.III.2014, 2 우 (DCS), 21.IV.2014, leg.: N.B..

Distribution within Iran: Kerman province (Current study).

General distribution: Western Palaearctic (Europe) (Yu et al., 2016), new record from Iran.

Hyposoter caudator Horstmann, 2008** (Fig. 1B)

Material examined: 1 ㅇ (DCS), Iran, Faryab, MT1 and MT2, 21.IV.2014, 1 ㅇ (DCS), 14.V.2014; 1 (으 (DCS), Jiroft, MT3 and MT4, 9.IV.2015, 1 우 (DCS), 2.V.2015, 1 (을, (DCS), 29.V.2015; 4우웟 (DCS), Maskoon, MT5 and MT6, 1.V.2015, 1윗 (DCS), 24.V.2015, 3우 (ZSM) 1ðิ (DCS), 18.VI.2015; MT8, 1 우 (DCS), Sarbijan, 21.IV.2014, 1 ㅇ (DCS), 14.V.2014, Leg.: N.B..

Distribution within Iran: Kerman province (Current study).

General distribution: Spain and Switzerland (Horstmann, 2008), new record from Iran. 
Genus Meloboris Holmgren, 1859

Meloboris collector (Thunberg, 1822)**

Material examined: 1어, Iran, Jiroft, MT3, 8.IV.2015; 1엉 Sarbijan, MT7, 29.III.2014, Leg.: N.B. (ZSM).

Distribution within Iran: Kerman province (Current study).

General distribution: Afrotropical, Oceanic, Palaearctic (Yu et al., 2016), new record from Iran.

Remark: The genus Meloboris is newly recorded from Iran.

Genus Sinophorus Förster, 1869

Sinophorus pleuralis (Thomson, 1887)**

Material examined: 1̧ิ (ZSM), Iran, Jiroft, MT3, 13.III.2015, leg.: N.B..

Distribution within Iran: Kerman province (Current study).

General distribution: Oriental, Palaearctic (Yu et al., 2016), new record from Iran.

Subfamily Cremastinae Förster, 1869

Genus Temelucha Förster, 1869

Temelucha lucida (Szépligeti, 1899)*

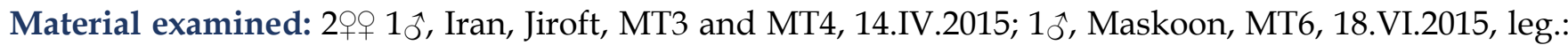
N.B. (DCS).

Distribution within Iran: Fars (Ghahari \& Jussila, 2010), Kurdistan (Mohammadi-Khoramabadi et al., 2016b; Kamangar et al., 2017), West Azerbaijan (Ghahari \& Jussila, 2011) and Kerman provinces (Current study).

General distribution: Western Palaearctic (Yu et al., 2016; Belokobylskij et al., 2019).

Temelucha schoenobia (Thomson, 1890)*

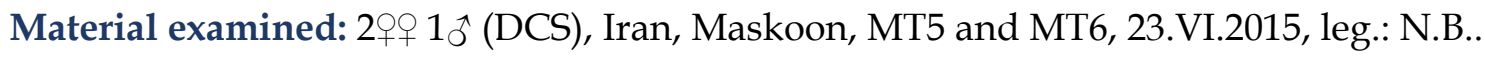

Distribution within Iran: Golestan (Masnadi-Yazdinejad \& Jussila, 2009) and Kerman provinces (Current study).

General distribution: Western Palaearctic (Yu et al., 2016; Belokobylskij et al., 2019).

Genus Trathala Cameron, 1899

Trathala hierochontica (Schmiedeknecht, 1910)*

Material examined: 1 ( (DCS), Iran, Jiroft, MT3, 9.IV.2015; leg.: N.B..

Distribution within Iran: Mazandaran (Masnadi-Yazdinejad \& Jussila, 2009) and Kerman provinces (Current study).

General distribution: North Africa, Western Palaearctic (Yu et al., 2016; Belokobylskij et al., 2019).

Subfamily: Mesochorinae Förster, 1869

Genus Mesochorus Gravenhorst, 1829

Mesochorus arenarius (Haliday, 1838)** (Fig. 1C)

Material examined: 1 ( (ZSM), Iran, Maskoon, MT5, 24.V.2015; leg.: N.B..

Distribution within Iran: Kerman province (Current study).

General distribution: Holarctic (Riedel, 2020), new record from Iran. 
Mesochorus pictilis Holmgren, 1860 (Fig. 1D)

Material examined: 1 ㅇ (ZSM), Iran, Jiroft, MT4, 14.IV.2015, Leg.: N.B..

Distribution within Iran: Kerman province (Mohammadi-Khoramabadi et al., 2016a); Current study.

General distribution: Holarctic (Riedel, 2020).

Subfamily Metopiinae Förster, 1869

Genus Exochus Gravenhorst, 1829

Exochus gravipes (Gravenhorst, 1820)*

Material examined: 1 ( (DCS), Iran, Jiroft, MT3, 21.IV.2014; leg.: N.B..

Distribution within Iran: East Azerbaijan (Mohammadi-Khoramabadi et al., 2020a) and Kerman provinces (Current study).

General distribution: Holarctic (Yu et al., 2016; Belokobylskij et al., 2019).
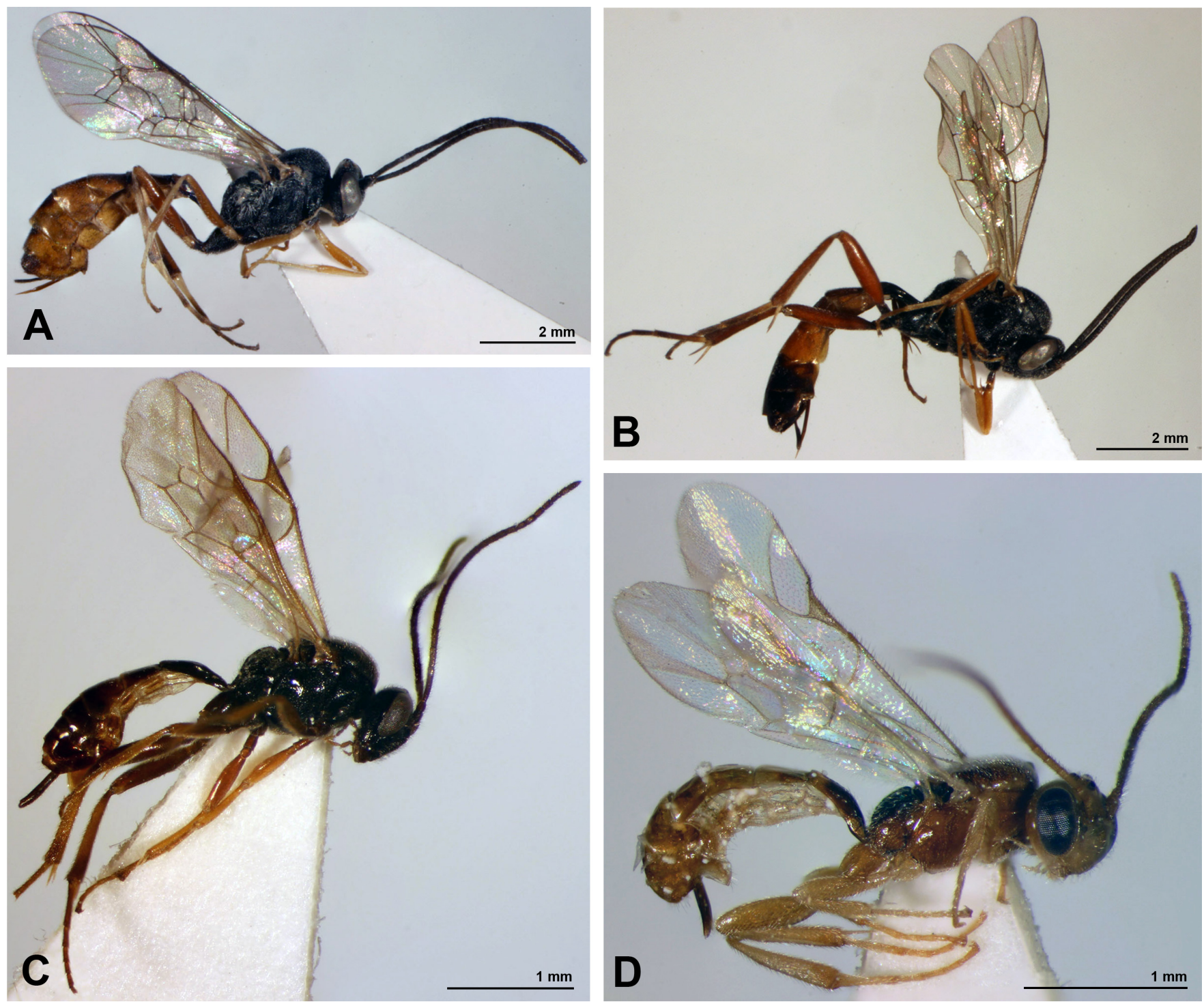

Figure 1. The female habitus of A. Hyposoter Barretti (Bridgman, 1881), B. Hyposoter caudator Horstmann, 2008, C. Mesochorus arenarius (Haliday, 1838) and D. Mesochorus pictilis Holmgren, 1860. 
Exochus mitratus (Gravenhorst, 1829)

Material examined: 4우 (DCS), Iran, Jiroft, MT3 and MT4, 21.IV.2014, leg.: N.B..

Distribution within Iran: Tehran (Masnadi-Yazdinejad \& Jussila, 2009), Fars, Hormozgan (Amiri et al., 2015b) and Kerman provinces (Mohebban et al., 2016).

General distribution: Holarctic (Yu et al., 2016; Belokobylskij et al., 2019).

Genus Metopius Panzer, 1806

Metopius (Cultrarius) turcestanicus Clément, 1930*

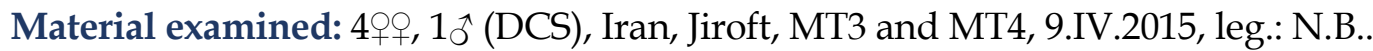

Distribution within Iran: Hormozgan (Amiri et al., 2015b), and Kerman provinces (Current study).

General distribution: Palaearctic (Tolkanitz, 2015; Yu et al., 2016).

Subfamily Ophioninae Shuckard, 1840

Tribe Enicospilini Townes, 1971

Genus Enicospilus Stephens, 1835

Enicospilus ramidulus (Linnaeus, 1758)*

Material examined: 1 ( (DCS), Iran, Maskoon, MT5, 18.VI.2015, leg.: N.B..

Distribution within Iran: Fars (Amiri et al., 2016a), Zanjan, Ardebil, West Azerbaijan, East Azerbaijan, Mazandaran (Johansson et al., 2021) and Kerman provinces (Current study).

General distribution: Afrotropical, Oriental, Palaearctic (Yu et al., 2016; Shimizu et al., 2020).

Tribe Ophionini Shuckard, 1840

Genus Ophion Fabricius, 1798

Ophion obscuratus Fabricius, 1798

Material examined: 5우 4 $\widehat{\text { ô }}$ (DCS), Iran, Jiroft, MT3 and MT4, 13.III.2015, leg.: N.B..

Distribution within Iran: Yazd (Zarepour-Ashkezari et al., 2010), Tehran, Golestan, Hormozgan, Kerman, Fars (Masnadi-Yazdinejad et al., 2010) and Mazandaran (Johansson et al., 2021) provinces.

General distribution: Neotropical, Oriental and Palaearctic (Yu et al., 2016).

Subfamily Tryphoninae Shuckard, 1840

Tribe Phytodietini Hellén, 1915

Genus Netelia Gray, 1860

Netelia (Netelia) dilatata (Thomson, 1888)

Material examined: 1우 (DCS), Iran, Maskoon, MT5, 1.V.2015, leg.: N.B..

Distribution within Iran: Not exactly defined (Kasparyan, 1981a), Kerman province (MohammadiKhoramabadi et al., 2020b).

\section{DISCUSSION}

According to the result of this survey 27 species of the Ophioniformes parasitoid wasps were identified in various agricultural ecosystems of Jiroft and Faryab counties, of which six species are first records for Iran. With this publication and other recently published studies (Schnee, 2018; Riedel, 2018, 2021; 
Riedel et al., 2019a, 2019b; Zardouei-Heydari et al., 2019, 2020a, 2020b, 2020c; Belokobylskij et al., 2019; Mohammadi-Khoramabadi et al., 2020a, 2020b; Falahatpisheh et al., 2021), the number of Iranian Ophioniformes group increased to 319 species as follows: Anomaloninae (17), Banchinae (38), Campopleginae (68); Cremastinae (35), Ctenopelmatinae (11); Hybrizontinae (1); Mesochorinae (5); Metopiinae (13); Ophioninae (63); Tersilochinae (14); Tryphoninae (54). The recorded Ophioniformes species in the current study includes nearly $8.5 \%$ of the known species of this group in Iran. Considering the number of singletons (collected species with one individual) (Chao et al., 2009) in this study, additional samplings or sampling arears require to detect more Ophioniformes species in the agricultural ecosystems of this region.
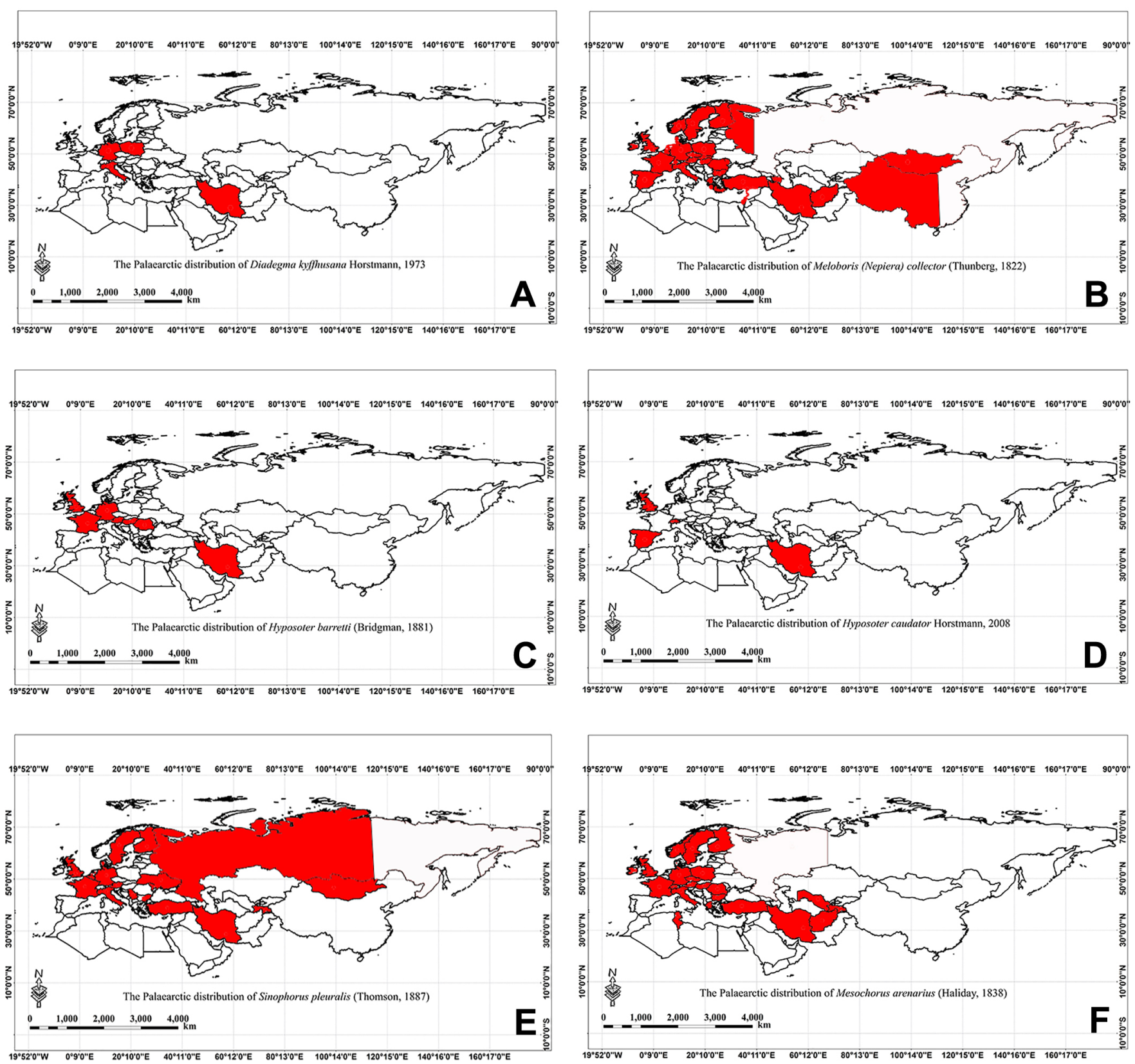

Figure 2. The Palaearctic distribution of A. Diadegma kyffhusana, B. Meloboris collector, C. Hyposoter Barretti, D. Hyposoter caudator, E. Sinophorus pleuralis and F. Mesochorus arenarius. 
Members of the subfamily Campopleginae with 15 species showed a very minor fraction of its real diversity in the studied agricultural ecosystems. Yet, despite being the prominent position of this subfamily from a biocontrol point of view, the number of reported host-association of campoplegines with major Iranian agricultural pests are still 15 relations (Mohammadi-Khoramabadi \& Ziaaddini, 2017). Future sampling and rearing programs will get a more complete picture of the ecological association of the Campopleginae in agricultural ecosystems. Geographical distribution of the newly reported Ophioniformes species have been extended in the Palaearctic region. Distribution map of $M$. collector, S. pleuralis and M. arenarius reached to the southern border of the Palaearctic (Fig. 2B, 2E, 2F). By reporting of $D$. kyffhusana, $H$. barretti and $H$. caudator from Iran, their Palaearctic distribution extended far away from their reported countries in Europe (Fig. 2A, 2C, 2D).

Elevation range distribution of the identified Ophioniformes was varied in the studied region. Twenty-one species have been collected in Jiroft site with the elevation of $855 \mathrm{~m}$ a.s.l. followed by Maskoon (1665 m): 12 species, Faryab (640 m): 11 species and Sarbijan (3043 m): 10 species (Table 2). Four species i.e., C. scyticus, $D$. fenestrale, $H$. barreti and $H$. caudator distributed in a wide altitudinal zone from $640 \mathrm{~m}$ in Faryab to $3043 \mathrm{~m}$ in Sarbijan. Diadegma majale has been found in Faryab $(640 \mathrm{~m})$ to Maskoon (1665 m). Casinaria tenuiventris and T. lucida have been collected in the elevations 855 (Jiroft) 1665 (Maskoon). The elevation distribution from 1665 to 3043 belonged to D. maculatum and M. collector. Some species were captured in one site (elevation band) as follow: D. kyffhusane in Faryab; $A$. cruentatum, D. anurum, S. pleuralis, T. hierochontica, M. pictilis, E. gravipes, E. mitratus, M. turcestanicus and O. obscuratus in Jiroft; M. arenarius, T. schoenobia and E. ramidulus in Maskoon; C. persicus and D. semiclausum in Sarbijan.

Table 2. Elevation range distribution of the Ophioniformes species in the south of Kerman province, Iran.

\begin{tabular}{|c|c|c|c|c|}
\hline Species & Faryab (640 m) & Jiroft (855 m) & Maskoon (1855 m) & Sarbijan (3043 m) \\
\hline A.cruentatum & & * & & \\
\hline C. scyticus & * & * & & * \\
\hline C. tenuiventris & & * & * & \\
\hline C. persicus & & & & * \\
\hline D. anurum & & * & & \\
\hline D. armillatum & * & * & & \\
\hline D. fenestrale & * & * & * & * \\
\hline D. kyffhusanae & * & & & \\
\hline D. maculatum & & & * & * \\
\hline D. majale & * & * & * & \\
\hline D. semiclausum & & & & * \\
\hline E. apostatus & * & * & & \\
\hline H. barretti & * & * & * & * \\
\hline H. caudator & * & * & * & * \\
\hline M. collector & & * & & * \\
\hline S. pleuralis & & * & & \\
\hline T. lucida & & * & * & \\
\hline T. schoenobia & & & * & \\
\hline T. hierochontica & & * & & \\
\hline M. arenarius & & & * & \\
\hline M. pictilis & & * & & \\
\hline E. gravipes & & * & & \\
\hline E. mitratus & & * & & \\
\hline M. turcestanicus & & * & & \\
\hline E. ramidulus & & & * & \\
\hline O. obscuratus & & * & & \\
\hline N. dilatata & & & * & \\
\hline
\end{tabular}


Table 3. Flight period of the Ophioniformes adults in Kerman province, Iran during 2015.

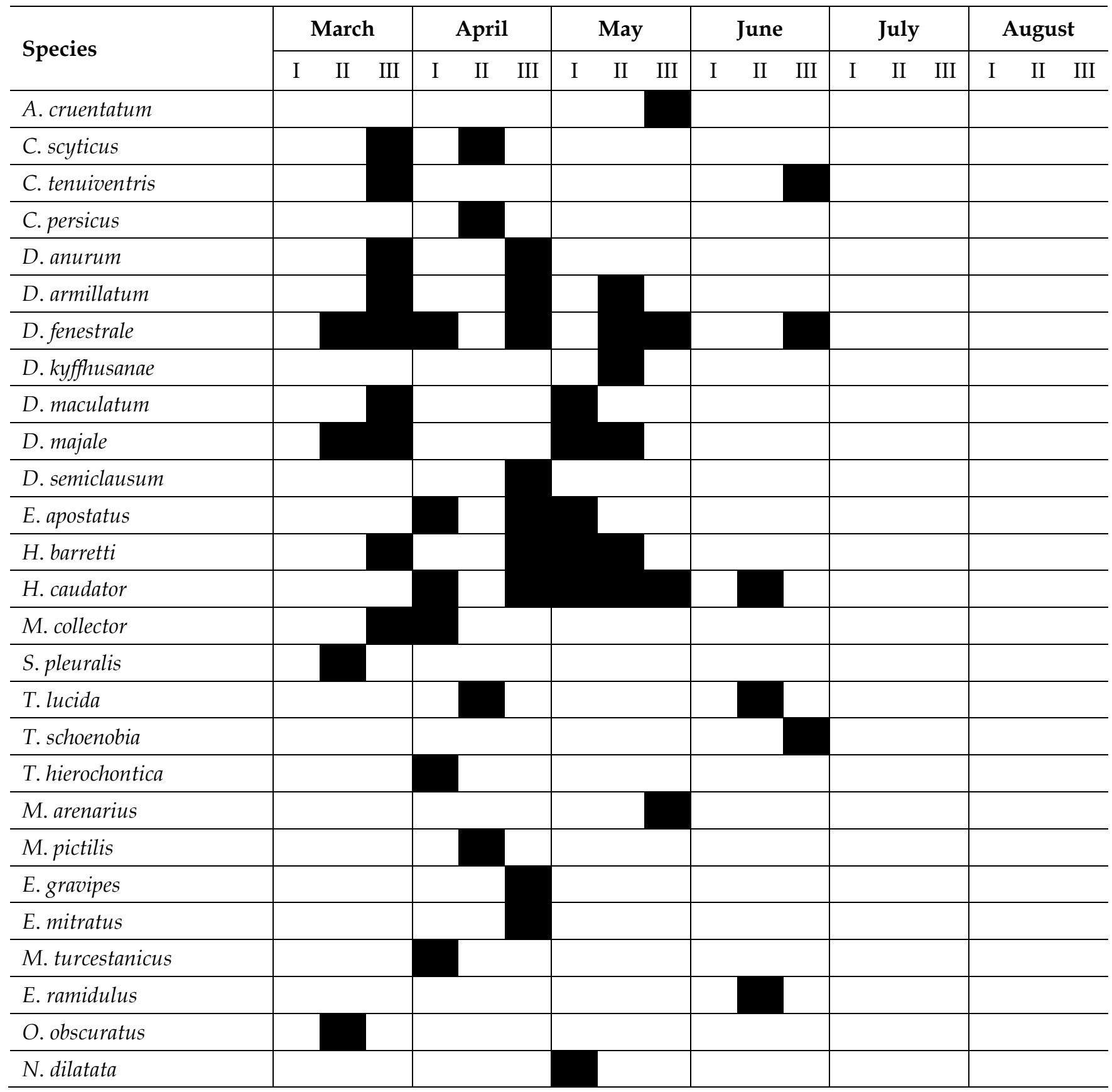

With describing C. persicus from Kerman province, the genus Cymodusopsis has currently two species in Iran as well as in the Palaearctic region. Its congener, Cymodusopsis rufator Riedel, 2019 has been reported from Khuzestan and Markazi provinces at altitude 45-53 m a.s.l. and 2090 m. a.s.l., respectively (Riedel et al., 2019a). By the available data on this genus, it can be noted that these two species is distributed at different altitudes in Iran. But future studies will reveal the true elevational distribution of these species in Iran.

The flight period of the Ophioniformes in the studied agricultural ecosystems was prolonged in the spring season, lasting about three months, from mid-March to late June (Table 3). The highest number of species were collected during April (16 species), followed by May (12 species). Based on the phenological data on this group (Shaw et al., 2016), the identified species may pass one generation on their host in the agricultural ecosystems of the studied region. 


\section{AUTHOR'S CONTRIBUTION}

The authors confirm contribution to the paper as follows: M.K., A.M.K.: conceptualization, supervision and project administration, and writing the manuscript; N.B.: collecting; M.R., A.M.K.: identification of specimens; M.K.: Funding acquisition. All authors have read and agreed to the published version of the Manuscript.

\section{FUNDING}

This project has been financially supported by Shahid Bahonar University of Kerman.

\section{AVAILABILITY OF DATA AND MATERIAL}

Not applicable.

\section{ETHICS APPROVAL AND CONSENT TO PARTICIPATE}

Not applicable.

\section{CONSENT FOR PUBLICATION}

Not applicable.

\section{CONFLICT OF INTERESTS}

The authors declare that there is no conflict of interest regarding the publication of this paper.

\section{ACKNOWLEDGMENTS}

This study was funded by a grant from Shahid Bahonar Universuty of Kerman to N. Bahremand for postgraduate studies. The authors are grateful to Dr. Marzieh Mokaram for help with map preparation.

\section{REFERENCES}

Abbasipour, H., Basij, M., Mahmoudvand, M. \& Masnadi-Yazdinejad, A. (2013) First report of the parasitoid wasp, Diadegma pusio (Hym.: Ichneumonidae), from Iran. Journal of Entomological Society of Iran, 32, 127-128.

Akbarzadeh-Shoukat, G. (2012) Larval parasitoids of Lobesia botrana (Denis and Schiffermuller, 1775) (Lepidoptera: Tortricidae) in Orumieh vineyards. Journal of Agricultural Science and Technology, 14, 267-274.

Amiri, A., Talebi, A.A., Jussila, R., Rakhshani, E. \& Hajiqanbar, H. (2015a) A study of the Iranian Cremastinae (Hymenoptera: Ichneumonidae). Journal of Insect Biodiversity and Systematics, 1, 87-100.

Amiri, A., Talebi, A.A., Riedel, M., Rakhshani, E. \& Hajiqanbar, H. (2015b) A survey of Metopiinae (Hymenoptera: Ichneumonidae) in southern Iran, with three new records. Journal of Crop Protection, 4, 519-531.

Amiri, A., Talebi, A.A., Jussila, R., Rakhshani, E. \& Hajiqanbar, H. (2016a) Study of the subfamily Ophioninae (Hymenoptera: Ichneumonidae) in southern Iran. Journal of Entomological Society of Iran, 35, 53-67.

Amiri, A., Talebi, A.A., Rey Del Castillo, C., Rakhshani, E. \& Hajiqanbar, H. (2016b) Study of the genus Lissonota (Hymenoptera: Ichneumonidae: Banchinae) in southern Iran. Journal of Entomological society of Iran, 36, 89-99.

Amiri, A., Talebi, A.A., Rakhshani, E. \& Hajiqanbar, H. (2017) First report of the genus Cymodusa (Ichneumonidae: Campopleginae) from Iran. Journal of Insect Biodiversity and Systematics, 3, 81-89.

Bahremand, N., Khayrandish, M., Mohammadi-Khoramabadi, A. \& Jussila, R. (2017) Syzeuctus irrisorius (Hymenoptera: Ichneumonidae: Banchinae): New genus and species record for the fauna of Iran. Journal of Entomological Society of Iran, 37, 285-288.

Barahoei, H., Rakhshani, E. \& Khajeh, N. (2012a) A survey on occurrence of Anomaloninae and Ophioninae (Hym., Ichneumonidae) in Sistan \& Baluchistan province, with a new record for fauna of Iran. Proceedings of the 17th National \& 5th International Iranian Biology Conference, 2012, September 4, Kerman, Iran. Shahid Bahonar University of Kerman, pp. 1-4.

Barahoei, H., Rakhshani, E. \& Riedel, M. (2012b) A checklist of Ichneumonidae (Hymenoptera: Ichneumonidae) from Iran. Iranian Journal of Animal Biosystematics, 8, 83-132. 
Barahoei, H., Schwarz, M., Kasparyan, D.R., Riedel, M., Khajeh, N. \& Rakhshani, E. (2013) Contribution on the knowledge of Ichneumonidae (Hymenoptera) in the northern part of Sistan and Baluchistan province, Iran. Acta Zoologica Bulgarica, 65, 131-135.

Barahoei, H., Rakhshani, E., Fathabadi, K. \& Moradpour, H. (2014) A survey on the fauna of Ichneumonidae (Hymenoptera) associating with alfalfa fields of Khorasan Razavi province. Iranian Journal of Animal Biosystematics, 10, 145-160.

Barahoei, H., Nader, E. \& Rakhshani, E. (2015) A survey on Ichneumonidae of Isfahan province, central Iran. Journal of Crop Protection, 4, 157-166.

Belokobylskij, S.A., Samartsev, K.G. \& Il'inskaya, A.S. (2019) Annotated catalogue of the Hymenoptera of Russia, Volume II, Apocrita: Parasitica. Proceedings of the Zoological Institute Russian Academy of Sciences, Supplement 8, 1-594. https://doi.org/10.31610/trudyzin/2019.supl.8.5

Broad, G.R. \& Shaw, M.R. (2016) The British species of Enicospilus (Hymenoptera: Ichneumonidae: Ophioninae). European Journal of Taxonomy, 1-31. https:// doi.org/10.5852/ejt.2016.187

Chao, A., Colwell, R.K., Lin, C.W. \& Gotelli, N.J. (2009) Sufficient sampling for asymptotic minimum species richness estimators. Ecology, 90, 1125-1133. https://doi.org/10.1890/07-2147.1

Ebadzadeh, H.R., Ahmadi, K., Mohammadnia Afrouzi, S., Abbas-Taghani, R., Abbasi, M. \& Yari, S. (2018) Iran Agriculture Statistics. Ministry of Jihad-e-Agriculture, Tehran. 420 pp.

Falahatpisheh, A., Fallahzadeh, M., Mohammadi-Khoramabadi, A., Jussila, R. \& Dousti, A.F. (2021) Additions to the Iranian fauna of Ichneumonidae (Hymenoptera: Ichneumonoidea) with first records of two genera and 13 species. Journal of Insect Biodiversity and Systematics, 7, 145-157.

Fathi, S.A.A., Bozorg-Amirkalaee, M., Sarfraz, R.M. \& Rafiee-Dastjerdi, H. (2012) Parasitism and developmental parameters of the parasitoid Diadegma majale (Gravenhorst) in control of Plutella xylostella (L.) on selected cultivars of canola. BioControl, 57, 49-59. https:/ / doi.org/10.1007/s10526-011-9373-7

Ghahari, H. \& Jussila, R. (2010) A contribution to the knowledge of ichneumon wasps (Hymenoptera: Ichneumonidae) from Iranian cotton fields and surrounding grasslands. Zoosystematica Rossica, 19, 357-360. https://doi.org/10.31610/zsr/2010.19.2.357

Ghahari, H. \& Jussila, R. (2011) A contribution to the knowledge of Ichneumon wasps (Hymenoptera: Ichneumonoidea: Ichneumonidae) from west Azarbaijan province, Northwestern Iran. Linzer biologische Beiträge, 43, 1277-1284.

Ghahari, H., Fischer, M. \& Jussila, R. (2012) Braconid and ichneumonid wasps (Hymenoptera, Ichneumonoidea) as the parasitoids of Plutella xylostella (L.)(Lepidoptera: Plutellidae) in Iran. Entomofauna, 18, $281-288$.

Ghahari, H. \& Schwarz, M. (2012) A study of the Ichneumonidae (Hymenoptera: Ichneumonoidea) from the Qazvin province, Iran. Linzer biologische Beiträge, 44, 855-862.

Ghahari, H. \& Jussila, R. (2016) Contribution to the knowledge of the fauna of Ichneumonidae (Hymenoptera: Ichneumonoidea) from Iran. Contributions to Entomology, 66, 119-124. https:/ / doi.org/10.21248/contrib.entomol.66.1.119-124

Golizadeh, A., Kamali, K., Fathipour, Y., Abbasipour, H. \& Jussila, R. (2008) Report of the parasitoid wasp, Diadegma anurum (Hym.: Ichneumonidae), from Iran. Journal of Entomological Society of Iran, 27, 15-16.

Hasanshahi, G., Abbasipour, H., Jahan, F., Askarianzadeh, A., Karimi, J. \& Rahimi, A.H. (2014) Natural parasitism of the diamondback moth, Plutella xylostella (L.) (Lep.: Plutellidae) by a larval parasitoid wasp, Diadegma anurum on different cauliflower cultivars. Archives of Phytopathology and Plant Protection, 47, 456-463. https:// doi.org/10.1080/03235408.2013.812285

Hasanshahi, G., Abbasipour, H., Moghbeli-Gharaei, A., Jussila, R. \& Mohammadi-Khoramabadi, A. (2015a) Nemeritis divida (Dbar, 1985) (Hym.: Ichneumonidae, Campopleginae), a new genus and species for the fauna of Iran. Applied Entomology and Phytopathology, 83, 79-80.

Hasanshahi, G., Abbasipour, H., Moghbeli-Gharaei, A., Jussila, R. \& Mohammadi-Khoramabadi, A. (2015b) First report of Hyposoter ebeninus a larval parasitoid of small cabbage butterfly, Pieris rapae from Tehran province. Applied Entomology and Phytopathology, 82, 185-186.

Hasanshahi, G., Abbasipour, H., Moghbeli-Gharaei, A., Jussila, R. \& Mohammadi-Khoramabadi, A. (2015c) First report of the parasitoid wasp, Hyposoter leucomerus Thomson (Hym.: Ichneumonidae, Campopleginae) from Iran. Journal of Biological Control, 29, 47-48. https:/ / doi.org/10.18641/jbc/29/1/75815 
Hooshyar, H. \& Vafaei-Shoushtari, R. (2013) Faunistic study of ichneumon wasps (Hym. Ichneumonidae) from Mazandaran province, Iran. Proceedings of the Second International Conference on Agriculture and Natural Resources, 2013, 25-26 December, Kermanshah, Iran. Razi University, pp. 914-917.

Hooshyar, H. \& Vafaei-Shoushtari, R. (2014) Faunistic study of ichneumon wasps (Hym. Ichneumonidae) from Mazandaran province, Iran. Journal of Entomological Research, 6, 191-202.

Hooshyar, H., Mohammadi-Khoramabadi, A. \& Vafaei-Shoushtari, R. (2017) First report of parasitoid wasps, Dimophora evanialis (Hym.: Ichneumonidae, Cremastinae), for the fauna of Iran. Applied Entomology and Phytopathology, 85, 125-126.

Horstmann, K. (2008) Neue westpalaarkitsche arten der Campopleginae (Hymenoptera: Ichneumonidae). Zeitschrift der Arveitsgemeinschaft Oesterreichischer Entomologen, 60, 3-27.

Horstmann, K. (2013) Revisionen von Schlupfwespen-Arten XVII. Mitteilungen der Münchner Entomologischen Gesellschaft, 103, 113-126.

Johansson, N. (2018) Review of the Swedish Enicospilus (Hymenoptera; Ichneumonidae; Ophioninae) with description of three new species and an illustrated key to species. European Journal of Taxonomy, 483, 1-21. https:// doi.org10.5852/ejt.2018.483

Johansson, N. \& Cederberg, B. (2019) Review of the Swedish species of Ophion (Hymenoptera: Ichneumonidae: Ophioninae), with the description of 18 new species and an illustrated key to Swedish species. European Journal of Taxonomy, 550, 1-136. https:// doi.org/10.5852/ ejt.2019.550

Johansson, N. (2021) Contribution to the subfamily Ophioninae (Hymenoptera: Ichneumonidae) of Southern Europe with the description of one new genus and 15 new species. Zootaxa, 5023, 301-334.

http://doi.org/10.11646/zootaxa.5023.3.1

Johansson, N., Ameri, A., Riedel, M., Talebi, A.A. \& Ebrahimi, E. (2021) Contribution to the Ophioninae (Hymenoptera: Ichneumonidae) of Iran with the description of 16 new species and an illustrated key to the Eremotylus of the Western Palaearctic. Zootaxa, 5023, 151-206. https:// doi.org/10.11646/zootaxa.5023.2.1

Kamangar, S., Lotfalizadeh, H., Mohammadi-Khoramabadi, A. \& Seyedi-Sahebari, F. (2017) Parasitoids of Tortrix viridana L. in Kurdistan province. Iranian Journal of Forest and Range Protection Research, 15, 176-186. https://doi.org/10.22092/ijfrpr.2018.109981.1264

Karimzadeh, J. \& Broad, G. (2013) Amendment to "report of the parasitoid wasp, Diadegma anurum (Hym.: Ichneumonidae), from Iran". Journal of Entomological Society of Iran, 33, 91-92.

Kasparyan, D.R. \& Tolkanitz, V. (1999) Fauna of Russia and neighbouring countries. Insecta Hymenoptera. Vol. III, No. 3. Ichneumonidae. Subfamily Tryphoninae. Nauka, Sanit-Petersburg, Russian Academy of Science, Russia. 404 pp.

Kasparyan, D.R. (1981a) 2. Tryphoninae. In: Medvedev, G.S. (ed.) Key to insects of European Territory of the USSR. Vol. 3. Hymenoptera. Part 3. Leningrad, Nauka: Opredeliteli Fauna SSSR, pp. 98-164.

Kasparyan, D.R. (1981b) A Guide to the Insects of the European Part of the USSR. Hymenoptera, Ichneumonidae. Opredelitel Faune SSSR. 688 pp.

Kishani-Farahani, H., Goldansaz, S.H. \& Sabahi, Q. (2012) A survey on the overwintering larval parasitoids of Ectomyelois ceratoniae in three regions in Iran. Crop Protection, 36, 52-57. https:// doi.org/10.1016/j.cropro.2012.01.018

Klopfstein, S., Riedel, M. \& Schwarz, M. (2019) Checklist of ichneumonid parasitoid wasps in Switzerland (Hymenoptera, Ichneumonidae): 470 species new for the country and an appraisal of the alpine diversity. Alpine Entomology, 3, 51-81. https://doi.org/10.3897/alpento.3.31613

Kolarov, J. (2016) Cremastinae (Hymenoptera, Ichneumonidae) from Turkey and adjacent countries with description of a new species. Linzer biologische Beiträge, 48, 1321-1326.

Lotfalizadeh, H., Masnadi-Yazdinejad, A. \& Saber, M. (2012) New records of the grape berry moth hymenopterous parasitoids in Iran. Munis Entomology and Zoology, 7, 284-291.

Masnadi-Yazdinejad, A. \& Jussila, R. (2009) A contribution to ichneumonid wasps of Iran (Hym.: Ichneumonidae): Anomaloninae, Cremastinae, Ctenopelmatinae, Mesochorinae, Metopiinae and Orthopelmatinae). Applied Entomology and Phytopathology, 76, 11-28.

Masnadi-Yazdinejad, A., Jussila, R. \& Riedel, M. (2010) The Iranian fauna of the subfamilies Acaenitinae, Banchinae, Campopleginae, Ophioninae and Tryphoninae (Hymenoptera: Ichneumonidae) with some new records. Entomologica Fennica, 21, 70-83. https:// doi.org/10.33338/ef.84511 
Mohammadi-Khoramabadi, A., Hesami, S. \& Shafiei, S. (2016a) A contribution to the knowledge of the fauna of Ichneumonidae in Rafsanjan county of Kerman province, Iran. Entomofauna, 37, 453-468.

Mohammadi-Khoramabadi, A., Kamangar, S. \& Lotfalizadeh, H. (2016b) Ichneumonid parasitoids of Tortrix viridana (Lepidoptera, Tortricidae) in the west of Iran. Linzer biologische Beiträge, 48, 681-691.

Mohammadi-Khoramabadi, A., Pourhaji, A., Lotfalizadeh, H. \& Riedel, M. (2017) Chromoplex picticollis (Hym.: Ichneumonidae) associated with Asteraceae capitulum: a genus and species new to Iran. Journal of Entomological Society of Iran, 37, 283-284.

Mohammadi-Khoramabadi, A. \& Ziaaddini, M. (2017) Report of Diadegma semiclausum (Hym.: Ichneumonidae, Campopleginae) parasitoid of the pistachio fruit hull borer moth, Arimania komaroffi (Lep.: Pyralidae) from Rafsanjan, Iran. In: Golchini, H., Sabouri, H. \& Taliei, F. (eds.) Proceedings of the Second National Congress of Monitoring and Forecasting in Plant Protection, 2017, March 9, Gonbad Kavous, Iran. Gonbad Kavous University, pp. 102-106.

Mohammadi-Khoramabadi, A., Hesami, S. \& Shafiei, S. (2018) First report of Campoletis scyticus (Hym.: Ichneumonidae, Campopleginae) from Iran. Applied Entomology and Phytopathology, 85, 277-278.

Mohammadi-Khoramabadi, A., Lotfalizadeh, H. \& Schwarz, M. (2020a) New records of the family Ichneumonidae (Hymenoptera, Ichnemonoidea) to the fauna of Iran. Journal of Insect Biodiversity and Systematics, 6, $229-237$.

Mohammadi-Khoramabadi, A., Riedel, M., Ziaaddini, M. \& Asadi, A. (2020b) New data on the fauna of Ichneumonidae from Kerman province with first records of two species to Iran. Journal of Entomological Society of Iran, 39, 447-457. https:/ / doi.org/10.22117/jesi.2019.126001.1306

Mohebban, S., Barahoei, H., Takalloozadeh, H.M., Madjdzadeh, S.M. \& Riedel, M. (2016) A survey of the Ichneumonidae (Hymenoptera, Ichneumonoidea) of Kerman province, south-east Iran. Journal of Insect Biodiversity and Systematics, 2, 419-437.

Nikdel, M. \& Diller, E. (2014) The first report of Diadegma armillatum (Hym.: Ichneumonidae) from Iran. Iranian Journal of Forest and Range Protection Research, 12, 76-77. https:/ / doi.org/10.22092/ijfrpr.2015.11139

Noroozi, J. (2020) Plant Biogeography and Vegetation of High Mountains of Central and South-West Asia. Springer, Cham, The Netherlands. 368 pp. https:/ / doi.org/10.1007/978-3-030-45212-4

Pénigot, W. (2021) Liste et clé d'identification pour les Anomaloninae de la faune de France, avec la description d'une espèce nouvelle du genre Therion (Hymenoptera, Ichneumonidae). Bulletin de la Société entomologique de France, 126, 253-328. https:/ / doi.org/10.32475/bsef_2182

Pourhaji, A., Lotfalizadeh, H., Farshbaf-Pourabad, R., Gharali, B. \& Mohammadi-Khoramabadi, A. (2016) Ichneumonid parasitoids (Hymenoptera: Ichneumonidae) of fruit flies (Diptera: Tephritidae) in the northwest of Iran. Journal of Insect Biodiversity and Systematics, 2, 193-202.

Quicke, D.L.J. (2015) The Braconid and Ichneumonid Parasitoid Wasps: Biology, Systematics, Evolution and Ecology. John Wiley \& Sons, Ltd., Chichester, West Sussex, UK. 681 pp. https:/ / doi.org/10.1002/9781118907085

Quicke, D.L.J., Laurenne, N.M., Fitton, M.G. \& Broad, G.R. (2009) A thousand and one wasps: a 28S rDNA and morphological phylogeny of the Ichneumonidae (Insecta: Hymenoptera) with an investigation into alignment parameter space and elision. Journal of Natural History, 43, 1305-1421. https:/ / doi.org/10.1080/00222930902807783

Riedel, M. (2017) Die westpaläarktischen Arten der Gattung Campoletis Förster (Hymenoptera, Ichneumonidae, Campopleginae). Spixiana, 40, 95-137.

Riedel, M. (2018) Revision of the Western Palaearctic species of the genus Casinaria Holmgren (Hymenoptera, Ichneumonidae, Campopleginae). Linzer biologische Beiträge, 50, 687-716.

Riedel, M., Ameri, A., Talebi, A.A. \& Ebrahimi, E. (2019a) Contribution to the Ichneumonidae (Hymenoptera) of Iran, with descriptions of seven new species. Linzer biologische Beiträge, 51, 361-390.

Riedel, M., Mohammadi-Khoramabadi, A. \& Khayrandish, M. (2019b) Two new species of Campopleginae (Hymenoptera: Ichneumonidae) from Iran. Zoology in the Middle East, 65, 1-5. https:/ / doi.org/10.1080/09397140.2019.1615751

Riedel, M. (2020) Contribution to the Mesochorinae of Sweden (Hymenoptera: Ichneumonidae). Entomologisk Tidskrift, 141, 95-120.

Riedel, M. (2021) The genus Syzeuctus Förster in the Western Palaearctic region and Central Asia (Hymenoptera, Ichneumonidae, Banchinae), with descriptions of 17 new species. Linzer biologische Beiträge, 52, 1013-1098. 
Sarafi, T., Barahoei, H., Madjdzadeh, S.M. \& Askari, M. (2015) A contribution to the knowledge of the Ichneumonidae (Hym.: Ichneumonoidea) from Neyriz county of Fars province, Iran. Journal of Crop Protection, $4,643-654$.

Schnee, H. (2014) Anomaloninae aus Israel und Palästina mit Beschreibung einer neuen Anomalon-Art (Hymenoptera: Ichneumonidae). Entomologische Zeitschrift, 124, 97-107.

Schnee, H. (2018) Typenrevision der von Hellén beschriebenen Anomaloninae (Hymenoptera, Ichneumonidae) und Übersicht über die finnischen Arten. Contributions to Entomology, 68, 151-175. https://doi.org/10.21248/contrib.entomol.68.1.151-175

Shamszadeh, M., Jafary, A. \& Bishe, G. (2015) Natural parasitism of Pharetrophora iranica (Hym.: Ichneumonidae) on saxaul seed moths larvae in Yazd province. Iranian Journal of Forest and Range Protection Research, 12, 160-162. https://doi.org/10.22092/ijfrpr.2015.13320

Shaw, M.R., Horstmann, K. \& Whiffin, A.L. (2016) Two hundred and twenty-five species of reared western Palaearctic Campopleginae (Hymenoptera: Ichneumonidae) in the National Museums of Scotland, with descriptions of new species of Campoplex and Diadegma, and records of fifty-five species new to Britain. Entomologist's Gazette, 67, 177-222.

Shimizu, S., Broad, G. R. \& Maeto, K. (2020) Integrative taxonomy and analysis of species richness patterns of nocturnal Darwin wasps of the genus Enicospilus Stephens (Hymenoptera, Ichneumonidae, Ophioninae) in Japan. ZooKeys, 990, 1-144. https:// doi.org/10.3897/zookeys.990.55542

Sooudi, M., Sadeghi, G.R., da Silva, J.A.T., Mohammadi Moghadam, M. \& Hokmabadi, H. (2007) Seasonal fluctuation, percent damage and larval natural enemy of grape berry moth (Lobesia botrana) in Tehran province (Shahriar Region) and Ghazvin province (Takestan region), Iran. Middle Eastern and Russian Journal of Plant Science and Biotechnology, 1, 69-71.

Tolkanitz, V.I. (2007) Ichneumon flies of the genus Exochus Gravenhorst (Hymenoptera: Ichneumonidae: Metopiinae) of the fauna of Palaearctic region. Russian Entomological Journal, 16, 339-358.

Tolkanitz, V.I. (2015) Ichneumon flies of the genus Metopius Panzer (Hymenoptera, Ichneumonidae, Metopiinae) of the Palaearctic fauna. Entomological Review, 95, 647-665. https://doi.org/10.1134/S0013873815050097

van Achterberg, C. (2009) Can Townes type Malaise traps be improved? Some recent developments. Entomologische Berichten, 69, 129-135.

Vas, Z. (2019) Contributions to the taxonomy, identification, and biogeography of the Western Palaearctic species of Campoletis Förster (Ichneumonidae: Campopleginae). Zootaxa, 4565, 373-382. https:// doi.org/10.11646/zootaxa.4565.3.4

Yu, D.S., van Achterberg, C. \& Horstmann, K. (2016) Taxapad 2016 - World Ichneumonoidea 2015. Taxonomy, Biology, Morphology and Distribution. Ontario: Nepean, Canada. On USB Flash Drive.

Zardouei-Heydari, M., Rakhshani, E. \& Mokhtari, A. (2019) Occurrence of the genus Erigorgus Forster (Hym., Ichneumonidae, Anomaloninae) in Eastern part of Iran with key to species. Journal of Insect Biodiversity and Systematics, 5, 69-78.

Zardouei-Heydari, M., Rakhshani, E., Mokhtari, A. \& Schwarz, M. (2020a) The genus Anomalon Panzer (Hymenoptera: Ichneumonidae: Anomaloninae) of Iran, with description of a new species. European Journal of Taxonomy, 662, 1-19. https://doi.org/10.5852/ ejt.2020.662

Zardouei-Heydari, M., Rakhshani, E., Mokhtari, A. \& Schwarz, M. (2020b) A faunistic overview of Temelucha Förster (Hym., Ichneumonidae, Cremastinae) in Iran. Turkish Journal of Zoology, 44, 355-374.

https://doi.org/10.3906/zoo-1912-42

Zardouei-Heydari, M., Rakhshani, E., Rousse, P., Mokhtari, A. \& Schwarz, M. (2020c) A new species of Pristomerus Curtis, 1836 (Hymenoptera, Ichneumonidae, Cremastinae) and key to the known species in Iran. Zootaxa, 4809, 187-194. https://doi.org/10.11646/zootaxa.4809.1.12

Zarepour-Ashkezari, A.R., Talebi, A.A. \& Vafaei-Shoushtari, R. (2009) Three new species records of Ichneumonid wasps (Hym., Ichneumonidae) from Yazd, Iran. Journal of Entomological Research, 1, 67-77.

Zarepour-Ashkezari, A.R., Talebi, A.A. \& Loni, S. (2010) Fauna of the ichneumonid wasps from Yazd, Iran. Journal of Entomological Research, 2, 13-20. 
مطالعه زنبورهاى كروه Hymenoptera: Ichneumonidae) Ophioniformes) در استان كرمان، به همراه شش ركورد جديد براى ايران

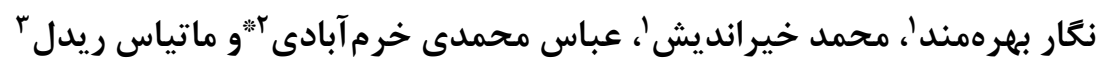

$$
\text { ا كروه كياهيزشكى، دانشكده كشاورزى، دانشخاه شهيد باهنر كرمان، كرمان، ايران. }
$$

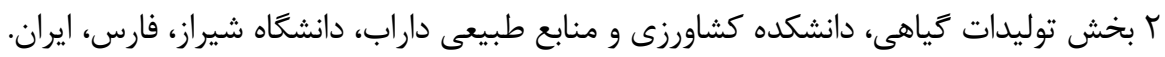

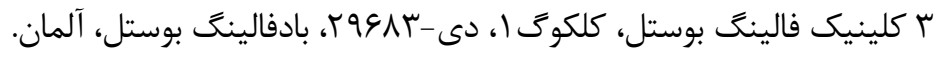

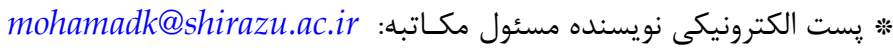

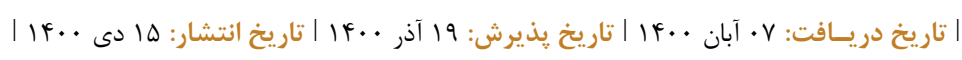

جكيـده: فون زنبورهاى گروه (Hym.: Ichneumonidae) Ophioniformes در بخش

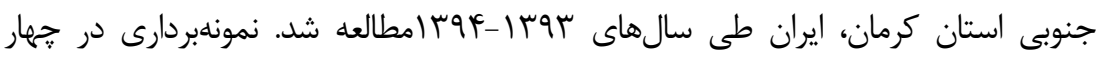

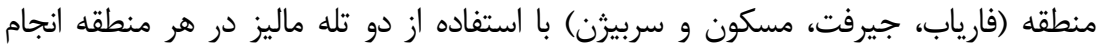

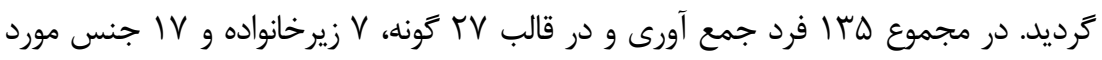
شناسايى قرار ترفتند. يك جنس (Meloboris Holmgren, 1859) و ش ش بار از ايران كزارش شد: Diadegma kyffhusanae Horstmann, 1973 Meloboris collector ،Hyposoter caudator Horstmann, 2008 (Bridgman, 1881) Mesochorus arenarius ،Sinophorus pleuralis (Thomson, 1887) ،(Thunberg, 1822) (Haliday, 1838)

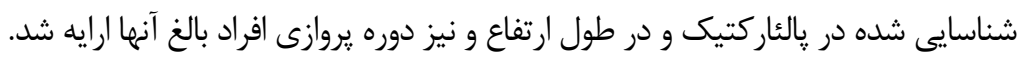
وازَّـان كليدى: انتلواره، طبقه بندى، يراكنش، تزارش جديد، مناطق مرتفع 